\title{
Covid-19: Black people and other minorities are hardest hit in US
}

\author{
Owen Dyer
}

Montreal

In the United States, black people are being admitted to hospital and dying in disproportionate numbers from the covid-19 pandemic. The Trump administration acknowledged the issue after a Washington Post analysis found that black majority counties had three times the coronavirus infection rate and almost six times the death rate of white majority counties. ${ }^{1}$

The excess deaths among African-Americans "are shining a very bright light on some of the real weaknesses and foibles in our society," said Anthony Fauci, director of the National Institute of Allergy and Infectious Diseases, adding that at least part of the problem was due to a higher burden of underlying medical conditions such as diabetes, hypertension, obesity, and asthma among African-Americans. "There's nothing we can do about it right now except to try and give them the best possible care to avoid complications," he said.

The true scale of the disparity is unknown because so few states and counties include racial data in their reporting. Hundreds of doctors joined Democratic lawmakers this week in calling for more detailed information.

\section{Racial disparity}

The current issue of the Morbidity and Mortality Weekly Report, compiled by the Centers for Disease Control and Prevention (CDC), ${ }^{2}$ shows that its reporting system has gathered racial data on just 534 covid-19 patients admitted to hospital, of about 40 000 admitted so far around the country. Of these, 261 (45.0\%) were non-Hispanic white and 192 (33.1\%) were non-Hispanic black, in a country where black citizens comprise less than $13 \%$ of the population.

Although the CDC has no comparable data on covid-19 deaths, data from localities that do report patients' race suggest an even worse disparity in that metric. In Chicago, black residents have been three times as likely to have the disease diagnosed as their white counterparts-and nearly six times as likely to die from it. In Milwaukee County, Wisconsin, and in hard hit Louisiana, black people account for $70 \%$ of the dead but for just $26 \%$ and $32 \%$ of those populations, respectively.

Surgeon general Jerome Adams, who is 45 and black, has said that he has high blood pressure, heart disease, and asthma and is prediabetic, "so I represent that legacy of growing up poor and black in America."

Other factors than underlying conditions are also likely to be at play. Many black people in the US work in essential jobs or in jobs that require in-person human interaction or cannot be done from home. Many also live in southern states, where Republican governors delayed lockdowns or played down the threat from the virus.

Black US residents are often suspicious of the health system, with a legacy of abuses such as the 1932-72 Tuskegee syphilis study, in which exclusively black participants were allowed to die untreated. And the US health system has been shown repeatedly to offer inferior care even to black people with the same conditions and insurance as white patients.

\section{"Invisible" communities}

Other minorities have also suffered disproportionately from covid-19. The Navajo Nation, the most numerous of the US's indigenous peoples, imposed a curfew across its vast territory in Arizona, New Mexico, and Utah this weekend to help stem the spread of a disease that has struck there with extra force. Many Navajo people lack piped water and must travel to get it.

Detailed data are lacking, and the 22 Navajo deaths reported so far are not far above the national average death rate, but when the CDC retrospectively reviewed $\mathrm{H} 1 \mathrm{~N} 1$ influenza deaths after 2009 it found that Native Americans had died at four times the national rate.

Perhaps the hardest hit of all is an invisible community, the undocumented immigrants. US Immigration and Customs Enforcement (ICE) continued to conduct raids even as lockdowns went into effect. While ICE has since promised not to arrest immigrants seeking medical care, its track record has left many terrified of going to hospital. Even taxpaying immigrants legally in the US and on a path to citizenship may now lose their right to live in the US if they use Medicaid services, under a rule imposed by the Trump administration last year. In immigrant communities, reports abound of people having died at home because they were afraid to seek care. Their numbers may never be known.

At least 19 children at an immigrant detention centre in Chicago have tested positive over the past week. In Sioux Falls, South Dakota, one of the largest US clusters of infection involves 300 largely immigrant employees at a meat processing plant.

Thebault $\mathrm{R}$, Williams $\mathrm{V}, \mathrm{Ba}$ Tran $\mathrm{A}$. The coronavirus is infecting and killing black American at an alarmingly high rate. Washington Post $2020 \mathrm{Apr} 7$. https://www.washingtonpost. com/nation/2020/04/07/coronavirus-is-infecting-killing-black-americans-an-alarminglyhigh-rate-post-analysis-shows.

2 Garg S, Kim L, Whitaker M, et al. Hospitalization rates and characteristics of patients hospitalized with laboratory-confirmed coronavirus disease 2019-COVID-NET, 14 states, 
March 1-30, 2020. CDC Morbidity and Mortality Weekly Report (MMWR) 2020 Apr 8. https://www.cdc.gov/mmwr/volumes/69/wr/mm6915e3.htm.

Deaths related to 2009 pandemic influenza A (H1N1) Among American Indian/Alaska Natives-12 states, 2009. CDC Morbidity and Mortality Weekly Report (MMWR) 2009;58:1341-4. https://www.cdc.gov/mmwr/preview/mmwrhtml/mm5848a1.htm.
Published by the BMJ Publishing Group Limited. For permission to use (where not already granted under a licence) please go to http://group.bmj.com/group/rights-licensing/ permissions 